\title{
UNEVEN MOBILITY EXPERIENCES: LIFE-STRATEGY EXPECTATIONS AMONG EASTERN EUROPEAN UNDERGRADUATE STUDENTS IN THE UK AND SPAIN
}

\author{
Silvia Marcu \\ Instituto de Economía, Geografía y Demografía \\ Consejo Superior de Investigaciones Científicas (CSIC) Spain \\ silvia.marcu@cchs.csic.es \\ C/Albasanz 26-28; 28037 Madrid; Spain
}

This article looks at the uneven mobility experiences of Eastern European (EE) undergraduate students within the European Union (EU) as a fundamental aspect of human intra-European mobility. It addresses the issue of student mobility by focusing on two samples of Romanian and Bulgarian undergraduates studying in the UK and Spain, after the EU enlargement towards the East. Based on 70 in-depth qualitative interviews, the study evaluates the motivations, experiences and expectations of students and their families in the context of lifecourse trajectories. I argue that the socio-economic situation of the country of origin, the different strategies used by EE students and their families, and the country they choose for study overseas - the UK or Spain - create uneven mobility and influence their future lifestrategy mobility after graduation. The main thematic findings, that is, mobility as a platform for permanent migration and family reunification, uncertain mobility as a tool for competition, and mobility for return, show the relation between the reasons why students study overseas and subsequent mobility aspirations. The conclusions highlight the need to integrate mobile students into the study of mobility as pivotal actors in the global circuit of mobility who favour both host and origin societies.

Key Words: student mobility, Eastern European, mobility strategies, Spain, UK.

\section{Introduction}

Mobility as expressed in temporary and permanent movement is an important element of post-communist restructuring in Europe. After the EU enlargement to Eastern Europe, the new context of open borders, which favours the free movement of people, provides an important arena for student mobility research. In line with the new mobilities paradigm, introduced by Sheller and Urry (2006, p. 207), and which highlighted that 'all the world seems to be on the move', it is argued that Eastern European (EE) migrants are not longer immigrants but free movers who are more likely to engage in temporary circular and 
transnational mobility rather than long-term permanent immigration. In this context, sending children overseas for education is a life-strategy used by parents to ensure their children's future, and indirectly their own, against the poverty and economic and social insecurities of their countries ( $\mathrm{Li}$ et al., 1996). Although there is a vibrant literature on student mobility (Ackers, 2005; Vinken, 2007; Waters, 2005; Ong, 1999) few studies (Balaz and Williams, 2004; Ferro, 2004) have focused on EE students and the different reasons why they choose to study in different EU countries.

This article studies the uneven mobility experiences of EE undergraduate students in the EU as a fundamental aspect of human intra-European mobility. Based on an in-depth empirical study, the paper seeks to address this gap in knowledge by evaluating the experiences and expectations of students and their families in the context of life-course trajectories. As Waters (2005, p. 359) argued, the 'overseas educational experience' is a significant objective of many middle-class families and migration is frequently the means to this end. Taking into account that the motivation for international student mobility must be related to subsequent mobility intentions with regard to the rest of the life course (Findlay et al., 2012), this article focuses on the mobility behaviour and patterns expressed in motivations, perceptions and expectations of EE students studying at universities in two EU countries: the UK and Spain. The study provides an analysis of uneven experiences of mobility, embracing and contrasting the different ways in which students from Eastern Europe choose mobility and what their expectations are at the end of their period of study. These expectations expressed by the students interviewed, which are: 1) mobility as a platform for permanent migration and family reunification, 2) uncertain mobility as a tool for competition, and 3) mobility for return, represent the main thematic findings of this paper.

In line with Waters (2005), who emphasizes the importance of education in the transnational strategies of lower-middle class families, this paper highlights the role of the family in 
students' decision to study at a foreign university. Although all the families of the student sample belong to the lower-middle class, I argue that various factors, such as the socioeconomic situation of the country of origin, the different strategies used by EE students and their families, and the country they choose for study overseas -the UK or Spain- create uneven mobility experiences and influence their life-strategy mobility after graduation. On the one hand, in the case of UK universities, EE undergraduates are attracted to the idea of study overseas by the promise of getting an education at a prestigious institution and the prospect of an international career. On the other hand, students who choose Spain for study overseas are mostly children of migrants in Spain, or returnees who were immigrants in Spain. The fact that their parents knew Spain and the Spanish language motivated them to choose Spain for study, with the prior expectation of returning to their country of origin after finishing their degrees. Students took advantage of the circumstances of their families, even though, in some cases, they would have preferred to study in the UK, as observed in the fieldwork. Therefore, their choice became, as Brooks and Waters (2009) have argued, a 'second chance' to study overseas. Following Waters (2005, p. 360), I conceive student mobility as part of a more general child-centred familial strategy of capital accumulation involving migration, mobility and transnational household arrangements.

This article contributes to an understanding of the complex geographies of students and to the emerging concepts within this area through the idea of uneven mobility experiences. After outlining the theoretical framework, the article traces the trends of EE student mobility towards the UK and Spain. Subsequently, I explain the methodology used, and I analyse the interviews with students and their families to highlight their uneven experiences and lifestrategy expectations. The conclusions foreground the need to integrate mobile students into the study of mobility as active players and pivotal actors in the global circuit of mobility. 


\section{Conceptualizing the research context}

Researchers in international student mobility (Findlay, 2011; Murphy-Lejeune, 2002) identify internationally mobile students as a migratory elite ready and willing to move and open to changes in their environment: language, personal entourage, lifestyle or working style. This article argues that the mobility of EE students has to be analyzed and conceptualized from the perspective of the new trends of mobility that were created after the enlargement of the EU to Eastern Europe. This mobility is still midway between migration inherited from previous generations, based on economic factors (to find a job, to access higher incomes), and mobility to study overseas, to take up a short work placement or travel (Balaz and Williams, 2004). As Kou and Bailey (2014, p.116) suggested, international experiences and opportunities are seen as a means of personal development and, more importantly, migration is seen as a career improvement strategy. This perspective has been developed in prior research, which has revealed that family and more specifically parents can encourage their children to migrate as a means of maintaining a family's social-class position (Cairns and Smith, 2011), or as a lifestrategy to improve the future well-being of the family.

To conceptualize student mobility in the family context, I use the broad concept of 'transnationalism', which has emerged as a cross-border field where migrants on the move for opportunities of work try to maintain and forge new relationships with their home country (Glick Schiller et al., 1992) and play an active role in shaping transnational space (Hannerz, 1996). The literature on transnational families (Waters, 2005; Robertson, 2013) shows that a transnational perspective facilitates an understanding of the ways in which families have utilized spatial strategies in the accumulation of different forms of capital within the family unit (Waters 2005, p. 362). This is where the work of Bourdieu (1984) is useful for understanding the significance of these practices for the social and cultural reproduction of the family, which affects the social and cultural capital of students in the education system. 
Simultaneously, Bourdieu's (1977) notion of habitus has provided an essential framework for understanding students' experiences. Habitus is taken here as '(...) a set of acquired characteristics which are the product of social conditioning (...) totally or partially common to people of similar social conditioning' (Bourdieu, 2005, p. 45). The habitus is socially constructed and thus access to capital acquisition is not universal but hierarchical, meaning that those families who have the 'wrong' type of cultural capital may find it difficult to adjust to situations where their 'type' of cultural capital is not commonplace (Savage et al., 2005).

Drawing on Bourdieu's concepts of habitus and cultural capital, I argue that for EE lowermiddle class families, financing the international education of their children presents, as Waters (2006, p. 188) noted, an 'opportunity to obtain a scarcer more valuable type of cultural capital in the form of a Western university degree'. Although parents of EE students have few resources, they make significant efforts to keep their children in foreign universities, especially in the UK. They are thus non-traditional students, defined by Christie (2007) as first generation university attendees from working class or minority backgrounds, that can experience much greater difficulties in 'fitting in' at university. In contrast to this notion of disadvantage, Lehmann (2009) suggests that a lower-middle class habitus can construct a moral advantage whereby the commonly held dispositions of students (maturity, responsibility and life experience) in fact act as tools which can give students the opportunity to realize their lower-middle class ambitions. Consequently, some of the 'young people with fewer opportunities' (Colley et al., 2007, p. 13) employ mobility strategies after graduation to improve their future careers.

As noted above, the life-course strategy approach is the conceptual link that helps understand future mobility decisions (Kou and Bailey, 2014, p. 119). Extending this argument along the lines of Findlay et al., (2012) and Madge et al., (2014), I suggest that the mobility of EE students should be considered in the context of mobile careers and mobile lives, in which 
students develop the capital required for 'employability'. As Murphy-Lejeune (2002, p. 100) noted, what distinguishes young European students from other nomads is 'the qualitative investment in their futures'. She goes on to claim that 'aware of economic competition, they appreciate the professional stakes of an international position' (ibid.) and believe that overseas education develops the 'mobility capital' which may help them to obtain such employment.

While the link between transnational student mobility and the decision to work overseas and to continue mobility after graduation has rarely been studied in the EU context, this complex issue has been widely studied in the Asia Pacific region (Robertson, 2013; Baas, 2010; Waters, 2005; Ong, 1999). This literature shows that studying overseas helps to prepare students for future mobility and competition. In the case of EE overseas students, previous education mobility is a very important determinant of mobility later in life, and increases the probability of living abroad. In this way, as Kuptsch (2006) noted, student mobility becomes a form of global talent recruitment embedded within the globalization of higher education. However, Morano-Foadi (2005, p. 133) argued that in Europe, the mobile highly-skilled are often driven by necessity more than choice, and the longer they are away the more complicated it is to return. For the case of Eastern Europe, Pinger (2010) shows that return migration is beneficial for economic development in the home country due to the repatriation of skills. Conceptualising return as a manifestation of transnationalism, I insert the return of EE students to their home countries, in the context of transnational family strategy (Waters, 2005), and I argue that professional, societal, and personal factors motivate their return (Alberts and Hazen, 2005).

Following these concepts, I propose looking at the uneven experiences of EE undergraduate students in the UK and Spain. The aspects of student mobility as a platform for permanent migration and family reunification, uncertain mobility as a tool for competition, and mobility 
for return, inserted in the broader context of transnationalism, together contribute to the uneven experiences of mobility, scarcely researched in the literature as mentioned above. In their work, Findlay et al., (2012, p. 124) note that the selectivity at the destination country level supports the thesis that the globalisation of higher education opportunities results in uneven experiences of international student flows. Their analysis shows that the globalisation of higher education is a highly uneven process and that student movers are very conscious of this in the choices they make (Findlay et al., 2012, p. 125). In turn, Sellar and Gale (2011, p. 115) state that the new kinds and degrees of mobility represent a significant factor sustaining unequal access to, and experience of, higher education for different student groups.

While in the UK research on student mobility has been substantial over the last decade (Madge et al., 2014; Mavroudi and Warren, 2013; Christie, 2007), in Spain there are few studies (Pineda, Moreno and Belvis, 2008; Vidal, 2003), and there is still no specific literature on the mobility of international students. Therefore, in this time of mobility, the question of uneven experiences of student mobility is essential to determine the different life-course strategies of EE undergraduates in the UK and Spain.

\section{Mobility of Eastern Europeans students to the UK and Spain}

The migration process of EE immigrants to the EU began in 1990 following the fall of the Berlin Wall and the beginning of the transition to democracy and free markets in Eastern Europe. The migration process of Romanians and Bulgarians is comprised of three periods: 1) The 1990-1996 period, which is characterised by the pioneers of migration; 2) The 1997-2002 period, which is characterised by restriction of movement due to EU migration policy; and 3) The period beginning in 2002 to the present, which is characterised by the opening up of the Schengen area borders to Romania and Bulgaria and its subsequent admission to the EU 
(2007). This marked a significant growth in mobility of Romanians and Bulgarians, above all to Italy and Spain. It is this last period which incorporates young immigrants and students, the mobile citizens of an expanded EU, who are seeking strategies to improve their studies and job prospects overseas (Marcu, 2012).

The EU countries choosing to open up their labour markets to workers from Bulgaria and Romania in 2007, the year of their accession, were Finland and Sweden, as well as the majority of member states that joined the EU in 2004. However, in 2012 there were 10 countries applying restrictions on the movement of workers from Bulgaria and Romania: Belgium, Germany, France, Ireland, Luxembourg, Malta, the Netherlands, Austria, and the UK. While Spain initially did not, in July 2011 it introduced restrictions for Romanian workers. However, as of 1st January 2014 transitional controls ended and Romanian and Bulgarian citizens now have full access to the EU labour market ${ }^{1}$. In 2014, there were an estimated 94,000 Romanians and 47,000 Bulgarians living in the UK (Office for National Statistics, 2014) and 922,286 Romanians and 178,518 Bulgarians living in Spain (Ministry of Employment and Social Security, 2014). In this context, the mobility of EE undergraduate students to EU universities is a phenomenon that has gained importance.

Young people from Eastern Europe have different motives, role models and relational dynamics shaping their spatial choices, including the desire to study at a well-recognised university (Findlay et al., 2012), the free movement within the EU, the impact of training on future career prospects, job opportunities, or relational ties created by transnational migrant communities (Collins, 2008). At the same time, moving to study overseas is a transnational family strategy that reflects the precariousness of work in the country of origin. Mobility is thus an informal process that may entail an inculcation of values emphasising the importance of moving overseas for success in education and in the labour market (Rao, 2010). 
This study focuses on the UK and Spain as destination countries to examine different background settings in terms of undergraduate student mobility. While Spain (together with Italy) is the country that received the most migrants from Romania and Bulgaria in the last decade, it has only emerged as a destination for undergraduate students during the past few years, and to date students are still underrepresented among EE migrants. In the case of the UK, the number of Romanian and Bulgarian students increased significantly in the last decade. Therefore, there are differences between the UK and Spain in terms of organizational systems and receiving international students.

On the one hand, the UK is the most popular host country destination for international students from Eastern Europe. The factors behind this success are: English is the native language; the UK has a tradition of excellence in education; it has a global system of applications through the UK Council for International Student Affairs (UKCISA); finally, the UK has a large labour market, which is very open to international talent. According to the UKCISA $^{2}$, Romania and Bulgaria are among the top EU sending countries when it comes to higher education in the UK. With 6,460 Romanian and 6,060 Bulgarian students respectively in the 2012-2013 academic year, these numbers are likely to increase annually (HESA, 2014). On the other hand, Spain has increased the number of foreign students enrolled only in recent years. As Morano-Foadi (2005, p. 146) argued, traditionally, southern European countries under-invest in research, attract fewer highly-skilled people from abroad, and fail to secure permanent positions for those who are in academia and science. The presence of EE students in Spain is still limited: 820 Romanians and 450 Bulgarians enrolled in 2011-2012 ${ }^{3}$. However, considering the fact that the number of students from immigrant families is booming, it seems likely that the number of students from these countries will increase.

\section{Methodology}


The study reported here is based on in-depth qualitative interviews. It is necessary to note that the interviewees do not include undergraduates studying in the UK and Spain within the EU Erasmus programme. The sample of students studying in the UK comprises degree students from high-performing bilingual public high schools with a high level of English (Cambridge accredited certificates), who are able to apply for admission to British universities through the online system UCAS (The University and College Admissions Centre in Great Britain). Those studying in Spain, for the most part, are the children of immigrants or returnees from Spain. Some of them studied in their home countries, while their parents worked in Spain, and after finishing their high school studies chose mobility to meet their parents in Spain, in order to return home together later, or even to migrate to other countries. Another category consists of the student children of returning migrants from Spain, with a certain level of accumulated capital that allowed them to open businesses in their countries of origin, and therefore be able to cover the costs of their children in Spanish universities, and also offer the possibility of incorporating their children into these businesses after completing their studies in Spain. Finally, I interviewed a number of students who had no parents or relatives in Spain, and who applied from their home countries. In all cases, mobility is for the purpose of study, which I have placed in the context of the opening up of the border and the EU enlargement towards Eastern Europe, which in turn allows for free circulation, and gives rights to citizens, with equal opportunities for citizens of the EU.

I conducted 60 in-depth semi-structured interviews with EE undergraduate degree students, during their study sojourn overseas: Romanians (30) 17 females and 13 males, and Bulgarians (30) 19 females and 11 males. The research was conducted between August 2011 and June 2012: in Spain (30) 15 Romanians and 15 Bulgarians: Madrid (12) Barcelona (10) and Valencia (8); and in the UK (30) 15 Romanians and 15 Bulgarians: London (11) Sheffield (9) and Edinburgh (10). 
Participants were identified by the following characteristics: Romanian and Bulgarian students (between 19 and 23 years old) who had moved from their country in the last two or three years and who had spent at least one year in the same city. Some of the interviewees came to participate in the project through Romanian and Bulgarian Student Associations in the UK and Spain, while others came through personal contacts and the subsequent snowball sampling.

The questions put to the EE undergraduate interviewees covered several areas. First, participants were asked to provide a brief account of their family and country context before their move and their experiences concerning applications to study in the UK or Spain. Second, we discussed their experiences of mobility in terms of study and job opportunities in the destination countries, and the extent to which these experiences had shaped their perceptions of the countries. Third, they were asked about their future plans, their professional and personal aspirations after graduation.

To further investigate the differences in mobility among young people, and to confirm the relationship to family life-strategies, I completed the fieldwork with 10 in-depth interviews conducted in November 2012 with the parents of students in: Romania, in the cities of Bucharest (2) and Galati (2); Bulgaria, in the cities of Sofia (2) and Vidin (2); and Spain (2). Parents explained the reasons why their children chose to study in the UK or Spain and whether they have adopted future life-strategies for their families.

Interviews were conducted in Romanian, English and Spanish and were recorded with the participants' permission. In this work, all participants appear under pseudonyms to ensure their anonymity. I transcribed and translated the interviews carried out. The interviews were coded and analysed using the ATLAS ti qualitative analysis software. The analysis of the information from the standpoint of codes, concepts and categories identified key relations between the data obtained and conclusions reached. 
Due to the large amount of data obtained, I have opted to use the thematic theme/sub-theme analysis, which is a well-established technique for reducing data in qualitative research (Grbich, 2007) ${ }^{4}$. The advantage of thematic analysis is its flexibility, both in terms of the variety of data sets it can be applied to and its compatibility with different research paradigms.

\section{Uneven experiences of mobility}

In what follows, I provide an analysis of my findings in relation to three key themes that together highlight the existence of uneven experiences of mobility and life-strategy expectations of EE undergraduates: mobility as a platform for permanent migration and family reunification; uncertain mobility as a tool for future competition; and mobility for return. As Findlay et al., (2012, p. 126) suggest, the emerging emphasis on differentiated mobility studies merits further investigation from the perspective of the student.

5.1. I will take my parents with me. Student mobility as a platform for permanent migration and family reunification

In their study, King et al., (2010, p. 7) pointed out that an international move as a student might be a prelude to immigration after the course of study has finished. In the particular case of Eastern Europe, the crisis of the transition to a market economy, which was accompanied by economic structural change and a dramatic increase in the unemployment rate, highlighted the difficulties faced by the lower-middle classes to deal with everyday life. Parents of students belonging to the lower-middle classes have educated their children at considerable financial expense in the high-quality schools of their respective countries. Thus, as Waters (2005, p. 370) noted, education is a part of a wider strategy of household capital 
accumulation. In several cities in Romania and Bulgaria, there are a number of highperforming bilingual public high schools. Pupils study English and Spanish from childhood, and later sit exams to demonstrate their English language proficiency. As Hoover-Dempsey and Sandler (1997) argued, parental engagement has a large and positive impact on children's learning. When they graduate from high school, students are ready to be admitted into EU universities.

Violeta told me:

I have studied Spanish and English since childhood, and I took the Cambridge and Cervantes certificate exams. This helped my application and subsequent admission to a foreign university. Finally, I chose to study in English in the UK, but I practise Spanish and I have been awarded an Erasmus grant for my fourth year of study. I will go to Barcelona.

(Female Romanian student, London, 22 years old)

Choosing to practise mobility for study is a family decision. Before applying, students consult with their parents as to what would be the best choice. Personal contacts were often very important in helping to decide on the country as well as the particular location, with many relying extensively on the internet for information on the UK and other countries, which they often compared to the UK. Applications for UK universities through the online system UCAS are valid for a five month period as they are conditional on the Baccalaureate test results obtained by the applicants in their countries.

Students and their families considered course fees and exchange rates prior to making their decision. It is known from the start that upon admission parents and relatives will be responsible for financing the cost of living in the destination country. Very often this is done at great expense and effort since only one family member works. My fieldwork shows that a significant number of families invest their resources (home sale, support of grandparents, land 
sale) to support their children in UK universities with the hope that after graduation they will be able regroup their families there. From this point of view, student mobility is used as a future resource against poverty and for saving the family.

Living expenses and tuition at university are excessive for EE families. According to official data from the Eurostat ${ }^{5}$, in 2013 the average net monthly salary in Romania was approximately €360 (£292), and €365 (£300) in Bulgaria in the same year. Therefore, it is almost imperative that students acquire a job in the UK. Until December 31, 2013, students from Romania and Bulgaria needed to apply for a Registration Certificate in order to work in the UK. Once they had a Registration Certificate they could be employed and could work up to 20 hours per week during term time and full time hours during the vacation periods. The time needed to obtain such permission could take between two and more than five months. And despite having permission, it was difficult to find employment. Consequently, most students had the support of their families as their only resource:

Otilia's mother told me:

Yes, we pay all the costs ... We have the help of my parents... They sold part of their land and contribute substantially to the cost of supporting my daughter. In addition, they consider it to be a very good investment for her future [...]. Here, we live badly... we put the heating on only when our daughter comes home for Christmas. When she leaves in January, we are cold ... but we are happy because she has very good grades, and maybe she can help us after graduation.

(Mother of a student in Edinburgh, Bucharest, 48 years old)

Thus, the decision to practise mobility for study may also be linked to plans for postgraduation settlement or labour migration (Perkins and Newmayer, 2013), with implications for potential students' location choices (Robertson, 2011). In my research, the opportunity to 
study overseas was seen as a transnational strategy, as an investment in the student's future for acquiring foreign cultural capital (Bourdieu, 1986) and facilitating their future integration in different cultural economies (Ong, 1999).

Parents confessed that they themselves study English and want to take advantage of their child's stay in the UK, and their relative knowledge of the British labour market so as to consider moving there to find work when their children graduate.

Todor's father confessed:

We invest heavily in their education. But not only this ... We are bound by strong family ties... he is the only child we have. Maybe in a few years, he will find a job in the UK and we can move there. I plan to sell the house here. Vidin has run out of jobs for people like me. (Father of a student in London, Vidin (Bulgaria), 45 years old)

Most of those interviewed indicate that they plan to remain there to work, and half of them want to reunite with their parents in the UK after graduation. As seen above, as of 1 January 2014, Bulgarians and Romanians may work freely in the UK, and that would facilitate the possibility of the families regrouping there.

Ioana confessed that:

I still have a year until graduation, but I just found work here, and of course I am not going back to my country. My plan is definitely to stay here. And I will bring my parents with me. I have to do this because my mother is unemployed and my father has little income. [... In Romania it is very difficult to survive for everyone. There are more opportunities here for my development, and for my family's development.

(Female Romanian Student, London, 21 years old) 
For some of them the desire to be close to their family members was not only a societal value, but also a moral obligation. We can see that in families where there has been a real decline in economic conditions and where there are no expectations of imminent prosperity in their countries, moving abroad has become an attractive proposition and a life-strategy for all the family. Observed transnationally, as Waters (2005, p.370) noted, this strategy involves capital accumulation and the social reproduction of the family unit. Thus, the children's education becomes the most important reason for parents' initial immigration to the UK. Consequently, this form of mobility for study may be used by students as a platform for permanent labour migration (Li et al., 1996) and family reunification.

5.2. I don't know what tomorrow will bring: uncertain mobility as a tool for future competition

The EE students' insecurity and precariousness overseas is currently exacerbated by the global economic crisis in the EU countries, which affects all young people. Like many of their peers coming from lower-middle class families, many of them are at a crossroads and keep practising mobility after completing their studies. This is especially the case in Spain, where in recent years the labour market stopped offering employment opportunities to immigrants. At the same time, the universities are going through a deep crisis in a country with a youth unemployment rate of $55 \%$. Of the total of 30 respondents, 15 (10 Romanians and 5 Bulgarians) studied high school in their home countries but currently live with their parents, immigrants in Spain. In a further 7 cases, the parents had lost their jobs and were currently seeking out mobility strategies in other EU countries or planning to return to their home countries. In another 5 cases, the parents were migrants who had already returned from Spain. The final 3 cases were respondents who had applied for study from their home countries, and 
who had no parents or relatives in Spain. This diversity of the respondents' profiles indeed reflects the different nature of their experiences and expectations of future mobility.

However, the fieldwork shows that almost all the students expressed dissatisfaction or frustration with the Spanish education system; particularly, the respondents who had applied from their home countries. It did not meet their expectations in terms of quality of training, funding, job availability, career progression, research opportunities and infrastructures. However, they are ready to project their skills and their image to promote themselves in the labour market.

As Irina noted:

I am unhappy with the quality of Spanish universities. I think the classes are too theoretical. But I have no choice. I have to finish and look for a job. Moreover I think that my stay in this country must be exemplary if I want to find my place in it.

(Female Romanian student, Valencia, 23 years old)

Given the difficulties in finding work, respondents continue to seek strategies for the future, and apply to other countries to be able to continue studying. Both the respondents who are children of immigrants who were unemployed in Spain and the respondents who applied from their home countries report that they feel 'insecure' in terms of being able to find work in Spain and that they will probably continue to practise mobility after graduation. They take positive 'time off' pathways through study programmes to other, especially Latin American, countries offering them certain facilities. Each year, Spain's Foreign Ministry grants scholarships for study in Latin America to graduates and postgraduates studying in Spain. ${ }^{7}$ Thus, respondents take advantage of this opportunity and learn to manage opportunities in the face of uncertainty.

Rossen told me: 
I don't know what tomorrow will bring. For now, I applied for and was granted a year's study in Colombia. I got this opportunity since I specialize in development cooperation. (Male Bulgarian student, Madrid, 23 years old)

Parents who live in Spain and who are currently unemployed explain that they agree with their child's decision. Moreover, they themselves are thinking of emigrating to other countries.

It is OK to go abroad because in Spain now we cannot do anything. We also want to emigrate to another country.

(Father of a student in Madrid, Madrid, 54 years old)

The interviews also highlighted the capacity of EE students to create future strategies to survive. Convinced that 'we must fight to become somebody', they learn to take control of their lives. They look for a place where their skills are needed and, as Robertson (2013, p. 72) argues, they must remain ever vigilant and flexible. Many of them discard Romania or Bulgaria as employment options in the future considering that:

Romania is my country but my circumstances mean that I must leave. Being realistic, Romania is a country where nobody is interested in anything.

(Male Romanian student, Barcelona, 23 years old)

However, despite the precariousness, some respondents pointed out that they needed to practise mobility in order to capitalise on job opportunities, and stressed that they applied to study at a well-recognised foreign university to prepare for future mobility and work competition. Therefore, a discussion on student mobility in the context of uncertainty and 
competition needs to examine another important factor that contributes to the great desire to study overseas. Most interviewees found the reputation of the UK Higher Education system and the prospect of participating in an 'international experience' daunting (Mavroudi and Warren, 2013, p. 265). EE students applying to the UK from high schools in their home countries do so knowing that UK universities rank among the best in the world. As Findlay et al., (2012, p. 125) argued, they seemed only to consider UK universities as elite.

Miroslava noted:

I always wanted to study English and I thought I could study in the UK. Previously, I researched what the best universities in the world were, and saw that the UK and Scottish ones were amongst the top in the world in the field of pharmacology and chemistry.

(Female Bulgarian student, Edinburgh, 21 years old)

In Spain, the admission system is much more complex and the universities do not have the same international recognition as those in the UK. Respondents that applied from their countries of origin to study in Spain told us about their difficulties. For them, Spain was a ‘second choice' (Brooks and Waters 2009) for studying overseas.

As Boris remembered:

I wanted to study in the UK, but it was not possible so I applied in Spain. I wanted to study Architecture, and despite the fact that I had a 10 in my country, I couldn't because here the grades are calculated on another basis, and I needed a 13. But it was absurd, because 13 did not exist in my country. So, finally I decided to study Communication Science. Still, I accept my lot, and I think I will successfully complete my studies and find a good job afterwards. (Male Bulgarian student, University of Valencia, 22 years old) 
Therefore, as Bourdieu's theoretical habitus orientation (1977) suggests, people's behaviour is the result of accepting the 'objective probabilities' of future success.

Despite the differences in the education systems in Spain and the UK, I note that some Romanian and Bulgarian students wishing to continue their mobility after graduating work towards the elite future 'to become someone different'.

As Sorina claimed:

I applied to study at the top universities. After finishing my Master's degree, I hope to move to the USA and work in the innovation department of a company assisting in the formulation of a new drug in the field of neuroscience.

(Female Romanian student, London, 21 years old)

Thus, as Bourdieu (1977, p. 87) argues, 'the habitus transformed by schooling underlies the structuring of our subsequent experiences'. Respondents are confident that practising mobility for study makes a student well-rounded in terms of skills, maturity, experience and personal development. They said that after becoming highly-skilled, what they most wanted was to travel widely to find the best employment prospects and to improve their financial situation. Similar to Bourdieu (2005), I found that some respondents from economically disadvantaged contexts are able to gain access to new resources associated with their educational and occupational success. They perceive precariousness as a tool with which to overcome current hardship. In becoming part of the global flow, they are forced to seek out life strategies or to apply to study at universities in several continents. Yet because of these 'disorienting dilemmas' practising mobility is not a painless process as it is the result of problems and barriers. The image of student mobility as a 'tool' is thus apt here. 
5.3. I will help in the development of my country. Mobility for return to the home country

This section reflects on mobility as a future life-strategy for return to the home country after graduation. My fieldwork shows that there are students, both Bulgarians and Romanians, considering returning to their countries of origin. While in the case of the UK just two students expressed interest in returning to their countries following graduation, in the case of Spain half of the cases recorded (8 Romanians and 7 Bulgarians) wished to do so. This difference between respondents studying in the UK and Spain shows the difference between the two countries in terms of job opportunities or higher incomes.

In the fieldwork, following Alberts and Hazen (2005), I identified several categories of factors motivating the return, which interact with each other: professional, societal and personal. Throughout the interviews, I asked participants to provide me with more detailed background about their respective home countries, for example, whether or not their home countries encouraged international students to return after the completion of their degrees, and how the students evaluated the labour markets in their respective fields back home. None of them knew of any government incentives for students to return and most reported that their governments were not concerned about the brain drain as far as they were aware.

As Doru explained:

The Romanian Government is more concerned about attracting foreigners than about losing Romanians. I think it should encourage our desire to study abroad, and realize that if it offers us opportunities after graduation, we will help remedy many negative aspects of our country. (Male Romanian student, Edinburgh, 22 years old)

For some of them, however, return means responsibility to the home society and a desire to reverse the brain drain or promote development in the home country. They consider that their 
return can have benefits for the economies of their countries: increased productivity, economic growth and competitiveness at the global level.

As Velina confessed:

I will return to help in the development of my country. It would be an insult to forget that I studied in Bulgaria until I was 18. I think Bulgaria deserves our return. Moreover, if you graduate here in the host country, there are a lot of people like you. You would just be adding a small amount of salt in an ocean. If you go back, it could make a much bigger difference there than here.

(Female Bulgarian student, Barcelona, 22 years old)

Personal factors were mentioned as a factor in making their decision by all participants who expressed a wish to return. Some of them consider return, principally, because they have parents who emigrated to and then later returned from Spain, and thus they have a family business employment opportunity.

As Sergiu stated:

I will work in the communications industry, as we have a family business in that sector. I will continue what my father started and he will help me.

(Male Romanian student, Barcelona, 22 years old)

In fact, Sergiu's father, who I interviewed in Bucharest, agrees with his son returning:

We are returning migrants from Spain. We're going to help him because now we have a business and we will continue working together. Furthermore, in Spain there is no work, so it is better for him to return home.

(Father of a student in Barcelona, Bucharest, 56 years old) 
As such, the return decision of students, which was taken even prior to their move to Spain, is part of the transnational strategy of lower-middle class families who are returned migrants from Spain. The analysis of the perceptions of the respondents confirms the report prepared by the League of EE Students (Manea, 2013) which affirms: what motivates students to return to their countries of origin is the closeness of the family and the possibility of working in the family, while the lack of government strategy for young graduates returning slows student return.

\section{Conclusions}

This paper focuses on the uneven mobility of EE (Romanian and Bulgarian) undergraduate students in the UK and Spain, after the enlargement of the EU to Eastern Europe, in the context of different transnational family strategies, and in terms of experiences and lifestrategy expectations. In this research, I have considered that Bourdieu's $(1977,1986)$ notions of habitus and capital have provided essential frameworks for understanding students' experiences. The research findings are in line with those of Waters (2005), and emphasize the role of the family as the agent of future life strategy expectations, as well as the importance of education in effecting the transnational strategies of lower-middle class families. At the same time, the research demonstrates an important relation between the reasons why students practise mobility for study and subsequent mobility aspirations. I found that freedom of movement and the possibility of studying overseas affect the decisions, motivations, expectations and meanings of the lives of EE students and their families both in the countries of origin and destination. There is strong evidence that the meanings and interpretations of mobility varied markedly with the context not only of study but of future mobility intentions (Findlay et al., 2012, p. 127). Importantly, I detected no differences in behaviour in terms of experiences and expectations among students from Bulgaria and Romania. 
I saw how many EE young people practise mobility for study, sometimes leaving their families behind to face poverty, looking for new opportunities to help them find new life horizons. Throughout the qualitative research, I distinguished different life-strategy expectations: mobility as a platform for permanent migration and family reunification, uncertain mobility as a tool for competition, and mobility for return. My data shows, on the one hand, that for students in the UK mobility for study is being used as part of a life-strategy to find a job and settle in the UK. They perceive their stay as permanent and use it as a future life-strategy to reunite their families following graduation. Most of the participants believed that studying in the UK had been beneficial overall to their career prospects. For them, the greatest professional payback from this investment would be to remain in the UK to work. On the other hand, in the case of Spain, I note that the diversity of the respondents' profiles highlights the different nature of their motivations, experiences and expectations of future mobility. In this way, some respondents expressed their intention to practise labour mobility, or study to other countries after graduating, while others, children of returnees who were immigrants in Spain, expressed their intention to return to their countries because they have the opportunity to work in a family business. Some respondents wanted to contribute to the development of their countries taking advantage of the knowledge acquired overseas.

This study specifically illustrates that students often use mobility as a transnational lifestrategy to improve both domestic and future career prospects. Thus, the life-course strategy of mobility helps them to increase their skill set and to better position themselves in the competitive labour market. For most respondents their self-perception was that their decision to study overseas was part of a strategy to enter an international career and develop an internationally mobile trajectory. They believed as argued Findlay et al., (2012, p.128) that their international experience could be deployed advantageously in their future career trajectories. Their departure can be interpreted as an opportunity to relocate, escape isolation 
and introduce EE highly-skilled mobility into global European mobility. Growing student mobility is also likely to lead to growth in workers' mobility. Thus, people who have been mobile as students are more likely to be mobile when they enter the labour market.

The results of this study also indicate the difference between the UK and Spain's highereducation systems through the vision of students. While the UK is the most popular host country destination, Spain has increased the number of foreign students enrolled only in recent years. This reality is clearly reflected in the perceptions of the interviewees, who also draw up future strategies depending on the circumstances of the country in which they study. While in the case of the UK, students expected to stay because they rely on finding employment following the completion of their studies, in the case of Spain, students faced not only the difficulty of obtaining employment but also the gap between academia and the world of employment.

Finally, through the analysis of the sample, I found that undergraduate student mobility is not necessarily permanent, but part of a global circuit of talent, involving students as active social and political agents (Robertson, 2010, p.644). They settle into the dynamic of uneven experiences of mobility as they start their professional lives. As mobility creates mobility, the way in which they have been able to adapt, places them in new contexts, which depend heavily on their future career, their joining the labour market and their mobility decisions in the future. Consequently, they are pivotal actors in the global circuit of mobility who favour both host and origin societies. From the students' perspective, mobility experience seems to release impulses to acquire human capital and personal growth, and may be a prelude to an international career, permanent migration or further mobility after graduation, or return to their countries of origin. 
I conclude that more research about motivations, experiences and expectations surrounding student mobility may help in understanding the causes and effects behind the production of uneven experiences of mobility.

\section{References}

Ackers, L., 2005. Moving people and knowledge: scientific mobility in the European Union. International Migration 43(5), 99-129.

Alberts, H. C., Hazen, H. D., 2005. There are always two voices: International Students' Intentions to Stay in the United States or Return to their Home Countries. International Migration 43 (3), 131-154.

Baas, M., 2010. Imagined Mobility. Migration and Transnationalism among Indian Students in Australia. Anthem Press, London.

Balaz, V., Williams, A. M., 2004. 'Been there, done that': international student migration and human capital transfers from the UK to Slovakia. Population, Space and Place 10 (3), 217237.

Bourdieu, P., 2005. Habitus. In: Hillier, J. and Rooksby, E. (Eds.), A Sense of Place. Ashgate, Aldershot, pp. 43-49.

Bourdieu, P., 1986. The Forms of Capital. In: Richardson, J.G. (Ed.), Handbook of Theory and Research for the Sociology of Education. Greenwood Press, New York, pp. 241-58. 
Bourdieu, P., 1984. Distinction: a social critique of the judgement of taste. Harvard University Press, Cambridge, M.A.

Bourdieu, P., 1977. Outline of a Theory of Practice. Cambridge University Press, Cambridge.

Brooks, R., Waters J., 2009. International higher education and the mobility of UK students. Journal of Research in International Education 8(2), 191 - 209.

Cairns D., Smith J., 2011. I wouldn't mind moving actually: Exploring Student Mobility in Northern Ireland. International Migration 49 (2), 135-161.

Christie, H., 2007. Higher education and spatial (im) mobility: nontraditional students and living at home. Environment and Planning A 39, 2445- 2463.

Colley, H., Boetzelen, Ph., Hoskins, B., Parveva, T., 2007. Social inclusion for young people: breaking down the barriers. Council of Europe Publishing, Strasbourg Cedex.

Collins, F., 2008. Bridges to learning: International student mobilities, education agencies and interpersonal networks. Global Networks 8, 398-417.

Ferro, A., 2004. Romanians abroad: a snapshot of highly skilled migration. Higher Education in Europe 29(3), 381-392.

Findlay, A., King R., Smith, F., Geddes, A., Skeldon, R., 2012. World class? An investigation of globalisation, difference and international student mobility. Transactions of the Institute of British Geographers 37(1), 118-131. 
Findlay, A., 2011. An Assessment of Supply and Demand-side Theorizations of International Student Mobility. International Migration 49(2), 162-190.

Glick Schiller, N., Basch, L., Szanton Blanc, C., 1992. Transnationalism: A new analytic framework for understanding migration. In: Glick Schiller, N., Basch, L., and Szanton Blanc, C. (Eds.), Towards a transnational perspective on migration: Race, class, ethnicity and nationalism reconsidered. New York, Academy of Sciences, pp. 1-24.

Grbich, C., 2007. Qualitative data analysis: An introduction. Sage, London.

Hannerz, U., 1996. Transnational connections: culture, people, places. Routledge, New York.

Higher Education Statistics Agency (HESA) 2014 <https://www.hesa.ac.uk/>(accessed 04.04.2014)

Hoover-Dempsey, K.V., Sandler, H., 1997. Why Do Parents Become Involved in Their Children's Education? Review of Educational Research 67(1), 3-42.

King, R., Findlay, A., Ahrens, J., 2010. International student mobility literature review. Report to HEFCE, and co-funded by the British Council, UK National Agency for Erasmus.

Kou, A., Bailey, A., 2014. "Movement is a constant feature in my life": Contextualising migration processes of highly skilled Indians. Geoforum 52, 113-122.

Kuptsch, C., 2006. Students and talent flow - the case of Europe. In: Kuptsch, C. and Pang, E. F. (Eds.), Competing for Global Talent, ILO, Geneva, pp. 33-61. 
Lehmann, W., 2009. Becoming middle class: how working-class university students draw and transgress moral class boundaries. Sociology 43, 631-647.

Li, F., L. N., Findlay, A., Jowett, A., Skeldon, R., 1996. Migrating to learn and learning to migrate: a study of the experiences and intentions of International student migrants. International Journal of Population Geography 2, 51-67.

Madge, C., Raghuram, P., Noxolo, P., 2014. Conceptualizing international education: From international student to international study. Progress in Human Geography doi: $10.1177 / 0309132514526442$.

Manea, M., (Ed.) 2013. SMART Diaspora, Liga Studentiilor Romani din Strainatate, Bucuresti. SMART Diaspora, The League of Romanian Students Abroad, Bucharest.

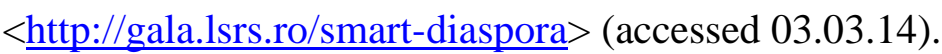

Marcu, S., 2012. Emotions on the move: belonging, sense of place and feelings identities among young Romanian immigrants in Spain. Journal of Youth Studies 15(2), 207-223.

Mavroudi, E., Warren, A., 2013. Highly skilled migration and the negotiation of immigration policy: Non-EEA postgraduate students and academic staff at English universities. Geoforum $44,261-270$.

Ministry of Employment and Social Security, Spain, 2014. Statistics of Migration. $<$ http://www.empleo.gob.es/es/estadisticas/Inmigracion_emigracion/index.htm $>$ (accessed 14.03.2014). 
Morano-Foadi, S., 2005. Scientific Mobility, Career Progression, and Excellence in the European Research Area. International Migration 43(5), 133-162.

Murphy-Lejeune, E., 2002. Student Mobility and Narrative in Europe. The new strangers Routledge, London.

Office for National Statistic, 2014. Bulgarian and Romanian migration to the UK. <http://www.ons.gov.uk/ons/taxonomy/index.html?nscl=Migration> (accessed 18.10.2014).

Ong, A., 1999. Flexible citizenship: the cultural logics of transnationality. Duke University Press, Durham.

Pineda, P., Moreno, V., Belvis, E., 2008. The Mobility of University Students in Europe and Spain. European Educational Research Journal 7(3), 273-288.

Pinger, P., 2010. Come back or stay? Spend here or there? Return and remittances: the case of Moldova. International Migration 48(5), 142-173.

Rao, N., 2010. Migration, education and socio- economic mobility. Compare: A Journal of Comparative and International Education 40(2), 137-145.

Robertson, S., 2013. Transnational Student-Migrants and the State: The Education-Migration Nexus. Palgrave Macmillan, New York.

Robertson, S., 2011. Student switchers and the regulation of residency: The interface of the individual and Australia's immigration regime. Population, Space and Place 17(1), 103-115. 
Robertson, S., 2010. Critical response to special section: international academic mobility.

Discourse: Studies in the Cultural Politics of Education 31(5), 641-647.

Savage, M., Bagnall, G. Longhurst, B., 2005. Globalization and belonging. Sage Publications Ltd, London.

Sellar, S., Gale, T., 2011. Mobility, aspiration, voice: a new structure of feeling for student equity in higher education. Critical Studies in Education 52(2), 115-134.

Sheller, M., Urry, J., 2006. The new mobilities paradigm. Environment and Planning A 38, 207-226.

Vidal, J., 2003. Quality Assurance, Legal Reforms and the European Higher Education Area in Spain. European Journal of Education 38(3), 301-313.

Vinken, H., 2007. New life course dynamics? Career orientations, work values and future perceptions of Dutch youth. Young 15(1), 9-30.

Waters, J., 2005. Transnational family strategies and education in the contemporary Chinese diaspora. Global Networks 5(4), 359-377.

Waters, J., 2006. Geographies of cultural capital: education, international migration and family strategies between Hong Kong and Canada. Transactions of the Institute of British Geographers 31, 179-192.

\footnotetext{
${ }^{1}$ European Commission 2014. End of restrictions on free movement of workers from Bulgaria and Romania, January 1, 2014 http://europa.eu/rapid/press-release MEMO-14-1_en.htm?locale=en (accessed 14.02.2014)

${ }^{2} \mathrm{UK}$ Council for International Student Affairs http://www.ukcisa.org.uk/Info-for-universities-colleges-schools/Policy-research--statistics/Research--statistics/International-students-in-UK-HE/\#International-students-
} 
in-UK-HE-by-domicile,-level-and-mode, \%3Cbr\%3E-European-Union-\%28EU\%29-\%28excluding-UK\%29and-non-EU,-2011-12- (accessed 18.03.2014)

${ }^{3}$ Immigration International Student Spain 2012. Government of Spain http://extranjeros.empleo.gob.es/es/RedEuropeaMigraciones/Estudios_monograficos/REM_Inmigracixn_de_Es tudiantes_Internacionales_ES.pdf (accessed 25.02.2014).

${ }^{4}$ The goal of thematic analysis is to locate the most common and salient themes in the data, which are capable of representing the data group in the form of a thematic map of a phenomenon or process

${ }^{5}$ Eurostat 2014 http://epp.eurostat.ec.europa.eu/portal/page/portal/labour_market/earnings/main_tables (accessed 22.03.2014)

${ }^{6}$ Survey of Active Service Population http://www.ine.es/daco/daco42/daco4211/epa0413.pdf (accessed 17.03.2014)

${ }^{7}$ Foreign Ministry-Cervantes Institute http://www.cervantes.es/bibliotecas_documentacion_espanol/becas_extranjeros_espana/becas_instituciones.htm (accessed 19.07.2014) 